\title{
EFFECTIVENESS OF ARTIFICIAL REPRODUCION ACIPENSER GUELDENSTAEDTII
}

\author{
Nikonorova Hanna*, Kireeva Irina \\ National University of Life and Environmental Sciences of Ukraine, Kyiv, Ukraine

\section{ЕФЕКТИВНІСТЬ ШТУЧНОГО ВІДТВОРЕННЯ ACIPENSER GUELDENSTAEDTII}

\section{Ніконорова Ганна, Кірєєва Ірина}

Received 11. 5. 2017

Revised 22.5. 2017

Published 29. 11. 2017

\begin{abstract}
The Russian sturgeon is vanishing species. A Russian sturgeon is also known as "Diamond Sturgeon" or "Tsar Fish" because of its majestic size and look. River Dam projects have affected almost all spawning ground of this species. It is estimated that the wild population of the Russian Sturgeon has reduced by $90 \%$ in just three generations of the species. Interest in replenishing wild stocks with hatchery-reared fish has created a need for an accurate methodological process of fertilization of both fish raised in aquaculture systems and fish in the wild. The caviar of the Russian sturgeon is one of the most sought after, and the flesh of the fish is also in demand always making poaching of the fish more frequent. The objective of this study was monitoring main indexes for Russian sturgeon in a period of spawning. Was holding a characterization of the main indicators of females of Russian sturgeon, a correlation between the main indicators.
\end{abstract}

Keywords: Russian sturgeon; fish; spawning; caviar; female

\section{Вступ}

Нестача плідників осетрових у природних умовах на сьогоднішній день $\epsilon$ дуже вагомою проблемою, яка ставить на меті важливу задачу - створення маточного поголів'я осетрових шляхом заводського відтворення. Вивчення та аналіз особливостей відтворення і вирощування анадромних видів осетрових, зокрема російського осетра, як з наукової, так і з практичної точки зору $\epsilon$ важливою задачею. Природоохоронний статус виду в Червоній книзі України - уразливий.

Головним чином, штучне відтворення осетра орієнтоване на отримання товарної продукції, а меншу частину цього напрямку займає отримання і вирощування життєстійкої молоді для вселення у природні водойми (Детлаф, 1981).

Покоління осетрових отриманих штучно і покоління від природного розмноження, не зовсім ідентичні. За своїми фізіологічними особливостями, за ростом і розвитком «заводська» молодь може бути дуже схожа з «дикою» молоддю, але при високому рівні біотехніки та випуску молоді найбільш високих кондицій, покоління отримане на заводі буде менш різноякісне, ніж від природного нересту, оскільки утворене від значно меншої кількості батьків (Афоніч,1971).

*Corresponding author: Hanna Nikonorova, National University of Life and Environmental Sciences of Ukraine, Kyiv, Ukraine, $\triangle$ annetnikonorova@gmail.com 
Тому в ситуації, що склалась, єдиною реальною можливістю збільшення обсягів виробництва осетрової продукції в Україні $\epsilon$ розвиток аквакультури цих риб, завдяки якій створюються умови для одержання товарної продукції вже протягом перших 2 - 4 років після початку виконання відповідних робіт (Третяк, 2010).

Основною метою дослідження був опис головних показників самок російського осетра в ІІ турі нерестової кампанії при заводському відтворенні (маса самок та їх ікри, робоча плодючість, \% запліднення та кількість розвиненої ікри), порівняння цих показників між самками та висновок щодо точності проведення робіт та успішності нерестової кампанії.

\section{Матеріали та методи}

Дослідження проводилися на повносистемному господарстві ПП «Фортуна-XXI» (продукція підтверджена сертифікатами CITES та ін.) у квітні-травні 2015 року. Джерелом водопостачання $\epsilon$ р. Дніпро. Об'єкт досліджень - російський осетр (Acipenser gueldenstaedtii). Предмет дослідження - технологія заводського відтворення російського осетра. Методи дослідження загальноприйняті у рибництві (Андрющенко, 2014). Переднерестове витримування плідників здійснювалось у садках та пластикових басейнах. Для стимуляції дозрівання статевих продуктів на господарстві використано еколого-фізіологічний метод А.Н. Державіна та Н.Л. Гербільського (1947). Стимулююча речовина - змішаний препарат (гліцериновий гіпофізарний препарат + сурфагон). Метод отримання статевих продуктів - відціджування. Метод запліднення ікри напівсухий метод В.П. Враського (1856), з використанням молок від власних самців. Ікру знеклеювали в апаратах модифікації Вейса, інкубація проводилась в апаратах «Осетр». Терміни дозрівання і готовності плідників до нересту визначали за графіком Т. А. Детлаф та А. С. Гінзбург (1969).

\section{Результати та їх обговорення}

У 2015 р. для отримання статевих продуктів російського осетра на заводі сформовано маточне стадо плідників, які використовувалися у нересті не одноразово. Нерестова кампанія проходила у II тури, в яких взяли участь 9 самок російського осетра: 5 екз. (№ 1, 2, 3, 4, 5) - в I турі та 4 екз. (№ 1, 2, 3, 4) - у II (табл. 1).

Таблиця 1 Рибоводно-біологічні результати роботи із самками Acipenser gueldenstaedtii у 2 турі нерестової кампанії 2015 року

Table 1 The fish breeding and biological results of study of Acipenser gueldenstaedtii females in the second tour of spawning 2015

\begin{tabular}{|l|c|c|c|c|c|c|}
\hline \multirow{2}{*}{ Ознака } & \multicolumn{7}{|c|}{ Тур } \\
\cline { 2 - 7 } & $\mathbf{1}$ & $\mathbf{2}$ & $\mathbf{3}$ & $\mathbf{4}$ & середнє значення & $\boldsymbol{\Sigma}$ \\
\hline Маса, , кг & 15 & 16,5 & 20,5 & 21 & 18,25 & - \\
\hline Час дозрівання, год. & 42 & 37 & 36 & 31 & 36,5 & - \\
\hline Маса ікри, кг & 3,1 & 3,5 & 4,1 & 4,2 & 3,7 & 14,9 \\
\hline Кількість ікринок в 1 г, екз. & 45 & 43 & 37 & 44 & 42 & - \\
\hline Робоча плодючість, тис. ікр. & 139,5 & 150,5 & 155,4 & 180,4 & 156,45 & - \\
\hline \% запліднення & 93,6 & 87,2 & 84,9 & 91,3 & - & - \\
\hline Кількість розвинутої ікри, тис. ікр. & 130,6 & 131,3 & 131,9 & 164,7 & 139,62 & - \\
\hline
\end{tabular}


Стимуляцію дозрівання статевих продуктів проводили еколого-фізіологічним методом Державіна. Самок I і II туру утримували в різних садках та басейнах. Оптимальна доза стимулюючої речовини склала - 4 мг/кг для самок і 2 мг/кг для самців. Серед проін 'єктованих самок II туру спостерігалась 100\% позитивна реакція на стимулюючу ін'єкцію.

Час дозрівання самок в контрольованих умовах коливався від 31 (самка № 4) до 42 годин (самка № 1) при середньому показнику 36,5 години.

Маса самок, які брали участь у II турі нерестової кампанії змінювалась в діапазон 15,0 (№ 1) 21 кг (№ 4).

Стан зрілості статевих продуктів особин визначали пробами за допомогою спеціального щупа, який уводили через стінки черевця до статевої залози на глибину 12 см.

На господарстві «Фортуна-XXI» для отримання ікри від самок використовували метод Подушки. Від самок II туру було отримано 14,9 кг ікри, в тому числі від № 1 () масою 15,0 кг - 3,1 кг; № 2 (†) масою 16,5 - 3,5 кг; № 3 (†) масою 20,5 кг - 4,2 кг; № 4 (†) масою 21,0 кг- 4,1 кг ікри. При цьому, максимальну кількість ікри віддала самка № 3 - 4,2 кг. У середньому на одну самку II туру отримано 3,7 кг ікри.

Від самок російського осетра отримано досить крупну ікру, що незначно відрізнялась за розмірами. Проте у самок з меншою масою відмічався й менший розмір ікринок. Так у самок № 1, 2, 3 кількість ікринок в 1 г склала 45, 43 і 37 відповідно. У найкрупнішої самки № 4 масою 21 кг ікра була найбільша, а кількість ікринок в 1 г склала 37. Середня кількість ікринок в 1 г по II турі нерестової кампанії - 42 екземпляри.

Показник робочої плодючості самок російського осетра варіював у межах 139,5 тис. ікр. (№ 1 ) - 180,4 тис. ікр. (№ 4 Ф). Робоча плодючість № 1 (ф) сягнула показника 139,5 тис.ікр, № 2 (ф) - 150,5 тис.ікр., у № 3 () цей показник склав 155,4 тис.ікр., а у самки № 4 робоча плодючість була максимальною - 180,4 тис. ікринок. В середньому робоча плодючість самок за II туру нерестової кампанії склала 156,45 тис. ікринок.

Протягом нерестової кампанії прослідковуються високі результати на всіх ланках технологічного процесу, що свідчить про якість плідників, а також правильні умови догляду та утримання їх у господарстві, високу якість кормів та відповідні гідрохімічні умови не лише у період відбору статевих продуктів, а і протягом усього періоду перебування риб на господарстві. План з отримання ікри російського осетра виконаний на $100 \%$.

\section{Висновки}

У II турі нерестової кампанії 2015 року на заводі використано маточне стадо плідників (4 самки). Стимулювання дозрівання статевих продуктів самок дало 100\% відповідь. Відбір статевих продуктів проводили методом Подушки, за допомогою якого отримано 14,9 кг ікри. Середня робоча плодючість склала 156,45 тис. ікринок. Середня кількість ікринок в 1 г самок становила 42 екз. План з отримання статевих продуктів самок двох турів виконано на $100 \%$.

\section{Література}

Андрющенко, А.І. 2014. Аквакультура штучних водойм. Частина 2. Індустріальна аквакультура. Київ, 586 c.

Третяк, О.М., Ганкевич, Б.О., Колос, О.М., Яковлєва, Т.В. Стан запасів осетрових риб та розвиток осетрової аквакультури в Україні. Київ, 442 с.

Афонич, Р.В., Гордиенко, О.Л., Солдатова, Е.В. 1971. Рыбоводная оченка производителей осетра разного веса и возраста по икре, личинкам и ранней молоди. Россия, $320 \mathrm{c}$.

Державин, А.Н. 1947. Воспроизводство запасов осетровых рыб. Азербайджан, 258 с.

Детлаф, Т.А., Гинзбург, А.С., Шмальгаузен, О.И. 1981. Развитие осетровых рыб. Созревание яии, оплодотворение, развитие зародышей и предличинок. Москва, 285 с. 